Proceedings

\title{
Limnological Characteristics and Diatoms in Lakes of North- Eastern Poland ${ }^{+}$
}

\author{
Monika Eliasz-Kowalska * and Agata Zofia Wojtal
}

Citation: Eliasz-Kowalska, M. Title. Proceedings 2021, 68, $\mathrm{x}$.

https://doi.org/10.3390/xxxxx

Published: date

Publisher's Note: MDPI stays neutral with regard to jurisdictional claims in published maps and institutional affiliations.

Copyright: (c) 2021 by the authors. Submitted for possible open access publication under the terms and conditions of the Creative Commons Attribution (CC BY) license (http://creativecommons.org/licenses/by/4.0/).
Institute of Nature Conservation, Polish Academy of Sciences, al. Adama Mickiewicza 33, 31-120 Kraków,

Poland; eliasz@iop.krakow.pl; wojtal@iop.krakow.pl

* Correspondence: eliasz@iop.krakow.pl

† Presented at the 1st International Electronic Conference on Biological Diversity, Ecology, and Evolution, 1531 March 2021

\begin{abstract}
Determination of the relationships between environmental factors and diatom assemblages is usually made for several hundred lakes spread over a large area. However the analysis of several lakes located near Lake Wigry also gives interesting results. Lakes in Wigry National Park (Poland) with broad similarity of geological origin show clear limnological, physical, and chemical differences. We report analysis of how these dissimilarities influence diatom assemblages. Unsupervised machine learning using Hierarchical Cluster Analysis showed that the studied lakes can be divided into three groups: (1) disharmonic, (2) harmonious with greater human impact on the environment, and (3) harmonious with a more limited human impact. In the dysharmonic group, the most distinctive dominant species was Tabellaria flocculosa, accompanied by Eunotia mucophila, E. rhomboidea, Stauroforma exiguiformis, Nitzschia gracilis as most frequent codominants. Harmonic lakes were dominated by Achnanthidium minutissimum and Encyonopsis microcephala. Most frequent codominant species were Fragilaria subconstricta, Brachysira microcephala, Encyonopsis cesatii and Eunotia arcubus. Studied lakes were abound in rare species such as Gomphonema vibrio, Fragilaria subconstricta, Aneumastus balticus, Navicula praeterita, N. subalpina or Sellaphora bacillum. The three groups vary in dominance structures, as reference to the Dominance Index (DI) made clear (mean values being: (1) $-70.54 \%$, (2) $-72 \%$, and (3) $-54.58 \%$, Generalized Linear Models with the categorical independent variable (group) showed significant differences between groups (for 1-3, 2-3) $p$ value $<0.05$ ). Lakes influenced by anthropopressure and disharmonic ones had the strongest dominance structure. DI differences between the groups are consistent with the Species Pool Hypothesis (SPH), while studied differences can be said to result from natural geological dissimilarities, as well as disparate anthropogenic impacts.
\end{abstract}

Keywords: lakes; disharmonic lakes; diatoms; dominance index; peat bogs; Wigry National Park; Poland 